\title{
WSPÓLCZESNE PRZEMIANY CENTRÓW MIAST W ŚWIETLE WYBRANYCH DOŚWIADCZEŃ AMERYKAŃSKICH I EUROPEJSKICH
}

\section{WSTĘP}

Centrum współczesnego miasta, jak stwierdzają Bohdan Jałowiecki i Marek S. Szczepański, ,jest znakiem [...], przestrzenia, która strukturalizuje obszar zurbanizowany, nadając mu sens i znaczenie" ${ }^{1}$. Jest fenomenem w przestrzeni, który budzi zainteresowanie nie tylko architektów i urbanistów. Wyznacznikami centrum sa takie elementy, jak: odrębność, skala, dostępność, identyfikacja i znaczenie ${ }^{2}$. Odrębność rozumiana jest jako swoiste oddzielenie, wyróżnienie w przestrzeni miejskiej obszaru centralnego pod względem obecności infrastruktury instytucjonalnej czy prezentowanych wartości architektonicznych i zastosowanej koncepcji urbanistycznej. Skala odnosi się do faktu, że w relacji do reszty miasta obszar centrum jest stosunkowo niewielki i z reguły zwarty. Dostępność wiąże się z określoną lokalizacją obszaru centrum $\mathrm{w}$ przestrzeni miasta i związanym z tym ułatwionym sposobem dotarcia do tej przestrzeni z wykorzystaniem środków komunikacji. Z kolei identyfikacja i znaczenie odnoszą się do odczuć społecznych związanych z tym obszarem. $\mathrm{Z}$ jednej strony mieszkańcy i turyści w sposób niejako naturalny identyfikuja centrum jako strefę, w której przebiegają najważniejsze procesy życia publicznego, z drugiej natomiast - odzwierciedla ono szczególne znaczenie, jakie ma dla społeczności miasta.

Coraz częściej podnosi się jednak kwestie „atrofii centrów” oraz utraty ich tradycyjnej roli ${ }^{3}$. Atrofia rozumiana jako zanik, stopniowe zmniejszanie się objętości, odnosi się w tym wypadku nie tyle do fizycznych aspektów centrów, ile raczej do ich funkcjonalności i struktury. Jak zauważają Jałowiecki i Szcze-

${ }^{1}$ B. Jałowiecki, M. S. Szczepański, Miasto i przestrzeń w perspektywie socjologicznej. Wykłady $z$ socjologii, t. 4, Scholar, Warszawa 2006, s. 391.

${ }^{2}$ Por. A. Wallis, Informacja i gwar. O miejskim centrum, PIW, Warszawa 1979, dla porównania M. Nowakowski podaje z perspektywy urbanistyczno-architektonicznej następujące wyznaczniki: wielkość przestrzennie ograniczonej koncentracji funkcji, różnorodność funkcji, unikatowość funkcji, stopień przestrzennej koncentracji funkcji i stopień nasycenia funkcjami dyspozycyjno-usługowymi, poziom rozwiąań przestrzennych (ich estetyczne i historyczne wartości wytwarzające odpowiedni klimat społeczny), wartość biourbanistycznego środowiska człowieka, por. idem, Centrum miasta. Teoria, projekty, realizacje, Arkady, Warszawa 1990, s. 8-9.

${ }^{3}$ Por. B. Jałowiecki, M. S. Szczepański, op. cit. 
pański, pełnione obecnie przez obszary centralne polskich miast funkcje zostały ograniczone do roli symbolicznej i turystycznej, a ich zagospodarowanie powoduje, że nie są obszarami „atrakcji usługowej, handlowej i kulturalnej dla mieszkańców miasta"4. Wydaje się, że prawidłowość ta nie jest czymśs wyjątkowym, jednakże jej obecność na gruncie polskim jest nieco spóźniona w stosunku do sytuacji miast Europy Zachodniej czy Ameryki Północnej. Także ścieżki rozwojowe, jakie przechodziły miasta polskie, europejskie i amerykańskie sa nieco odmienne, a w efekcie sposoby radzenia sobie $\mathrm{z}$ negatywnymi tendencjami są różne. Punktem wyjścia rozważań nad stanem centrów jest zagadnienie funkcjonowania przestrzeni publicznej w miastach jako miejsca, które jest celem dla użytkowników.

\section{PRZESTRZEŃ PUBLICZNA - PRZESTRZEŃ UŻYTKOWA - PRZESTRZEŃ UŻYTKOWNIKA}

Coraz częściej podnosi się, że planowanie przestrzeni publicznej oraz przestrzeni miast staje się zupełnie nową dziedzina, która musi szybko i skutecznie odpowiadać na zmiany pojawiajace się społeczeństwie ${ }^{5}$. Przed II wojna światową ludzie masowo korzystali z przestrzeni miejskiej bez względu na jej jakość i posiadaną ofertę. Współcześnie liczba zachęt do pozostania w domach lub bezkolizyjnego przemieszczania się do wybranych miejsc w przestrzeni (podmiejskich sklepów, centrów rozrywki, kina czy basenu) wymaga, aby projektanci zaczęli tworzyć przestrzenie, które przede wszystkim przyciagaja użytkowników ${ }^{6}$.

Równolegle pojawiają się jednak takie opinie, jak Williama H. Whyte’a, który stwierdził, że „trudno jest współcześnie zaprojektować przestrzeń miejska tak nieudolnie, aby ludzie z niej nie korzystali, a jednak wiele takich prze-

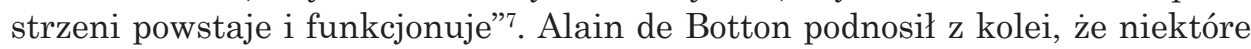
z działań w przestrzeni miejskiej sa „, zwykle dziełem kilku ludzi, ani specjalnie grzesznych, ani obdarzonych złą wolą [...] a mimo to udaje im się w ciagu kilku tygodni uruchomić projekt, który zrujnuje pejzaż na trzysta lat lub dłużej”.

Sam zatem fakt, że dana przestrzeń jest z definicji przestrzenią publiczna, nie sprawia jeszcze, że w taki sposób zafunkcjonuje. Co więcej, nawet przestrzeń wykorzystywana w danym momencie przez użytkowników nie stanowi gwarancji sukcesu, gdyż nie ma pewności, że za kilka lat wzorce korzystania z niej nie ulegna zmianie. Jan Gehl i inni podnoszą, że pierwotnie przestrzeń centrum miasta spełniała trzy podstawowe funkcje - miejsca spotkań, handlu i obszaru komunikacji wiążącego pozostałe miejskie obszary. Współcześnie zamożniejsze społeczeństwa traktują ją niemal wyłącznie jako przestrzeń wy-

${ }^{4}$ Ibidem, s. 393.

5 J. Gehl, L. Gemzoe, S. Kirknaes, B. S. Sondergaard, New City Life, The Danish Architecture Press/ Arkitektens Forlag, Copenhagen 2006.

${ }^{6}$ Ibidem.

${ }^{7}$ W. H. Whyte, City: Rediscovering the Center, University of Pennsylvania Press, Philadelphia 2012, s. 1 (tłum. własne).

${ }^{8}$ A. de Botton, Architektura szczęścia, czuty barbarzyńca, Press, Warszawa 2010, s. 252. 
poczynku, rekreacji i rozrywki9. Jeśli nie spełnia tych kryteriów, mieszkańcy traktuja ją jako przestrzeń użytkową i korzystają z niej tylko, jeśli muszą. Wciąż bowiem w centrach zlokalizowane są urzędy administracji różnych szczebli, kościoły czy muzea. Jaka jest zatem różnica między przestrzenią użytkową a przestrzenią użytkownika?

Wydaje się, że przestrzeń użytkowa jest przede wszystkim przeszkodą do pokonania w celu zaspokojenia jakiejś potrzeby zlokalizowanej w jej obrębie. Przy czym potrzeba ta nie jest zaspokajana przez stricte przestrzeń, a przez inne obiekty i instytucje, które w niej funkcjonuja. Stopień dostosowania przestrzeni użytkowej do potrzeb kierowcy/pasażera/przechodnia może być zróżnicowany. Może być ona postrzegana jako wygodniejsza/mniej wygodna, tańsza/ droższa lub krótsza/dłuższa. Desygnuja ją przede wszystkim odległość w sensie fizycznym oraz odległość rozumiana jako czas i koszt dotarcia do danego miejsca w niej zlokalizowanego. Ogół tych czynników pozwala określić ją jako mniej lub bardziej przyjazna.

Przestrzeń użytkownika natomiast jest celem sama w sobie. Prezentuje ofertę, która przyciaga ludzi chcących i gotowych spotkać się z nia, spędzić w niej czas, zaistnieć w niej. Spełnia wszystkie warunki dobrej przestrzeni użytkowej - łatwo i tanio można do niej dotrzeć, przemieszczanie się w niej nie nastręcza dodatkowych trudności. Dodatkowo samo przebywanie w przestrzeni użytkownika może być źródłem przyjemności i sposobem na zaspokojenie potrzeb. Posiada specyficzny potencjał, oferuje możliwości i stwarza użytkownikom szanse łatwego i dogodnego skorzystania z nich. Nieustannie zabiega o ich uwagę i oferuje im nowe doznania, jak bowiem twierdzi de Botton, „zła architektura [w tym także planowanie - dop. A.B.] jest w tym samym stopniu porażką projektancka, co psychologiczną"10.

\section{WSPÓŁCZESNE CENTRA MIAST AMERYKAŃSKICH I EUROPEJSKICH - TRENDY I REALIZACJE}

Marek Gachowski postuluje, że bez względu na strukturę przestrzenną i funkcjonalną obszaru centrum, choćby najsilniej stymulująca określone zachowania społeczne, niezbędne jest otwarcie społeczności na przyjęcie takiej stymulacji ${ }^{11}$. W przeciwnym razie nawet najlepiej zakomponowana przestrzeń, niosąca ze sobą szereg znaczeń i kontekstów oraz oferująca całą gamę atrakcji pozostaje interesująca tylko dla odbiorców z zewnątrz, a sami mieszkańcy miasta nie są zainteresowani przebywaniem w niej. Wynika to w dużej mierze $\mathrm{z}$ faktu, że wspomnianemu przewartościowaniu uległy ich potrzeby i oczekiwania, w ślad za czym pojawiły się w mieście inne przestrzenie (głów-

\footnotetext{
9 J. Gehl, L. Gemzoe, S. Kirknaes, B. S. Sondergaard, op. cit., s. 172-174.

${ }^{10}$ A. de Botton, op. cit., s. 246.

${ }_{11}$ M. Gachowski, Kwestia celowości istnienia centrum miasta $w$ warunkach transformacji społeczno-urbanistycznej, w: J. Słodczyk (red.), Przemiany struktury przestrzennej miast $w$ sferze funkcjonalnej i spotecznej, Wyd. UO, Opole 2004, s. 87-94.
} 
nie centra handlowe), które zaspokajaja je szybciej, skuteczniej i w bardziej wygodny sposób.

Pojawia się jednak kolejne pytanie: W jakiej mierze przestrzenie te sa reakcją na nowe potrzeby, a w jakiej same doprowadziły do ich wykreowania? Odpowiedzi należałoby szukać w krajach, gdzie zapoczątkowano te zjawiska, konkretnie w Stanach Zjednoczonych.

Amerykańskie malle były odzewem na proces suburbanizacji. Lokowano je w rozległych podmiejskich dzielnicach, których monotonna zabudowa rozciagała się na dziesiątki kilometrów kwadratowych. Jak podkreśla Tomasz Nawrocki: „W tych warunkach były jedyną możliwością zrobienia zakupów, pójścia do kina czy kawiarni. Ale czym innym jest postawienie centrum na peryferiach [...], a czym innym w samym środku miasta. Kosztem życia społecznego"12. Po pewnym czasie zaczęto obserwować stopniowe wyludnianie się obszarów centralnych i brak zainteresowania odbiorców ich oferta, głównie handlowa. Podjęto zatem działania mające na celu zbudowanie pewnych wzorców korzystania z centrów, uznając konsumpcyjne preferencje i oczekiwania mieszkańców. W efekcie w Stanach Zjednoczonych, obok peryferyjnych malli, zaczęły powstawać centra handlowe w dzielnicach śródmiejskich. Początkowo miały charakter klasycznych centrów, wydzielonych w przestrzeni miasta obszarów, czasem nawet o powierzchni całych kwartałów zabudowy, które koncentrowały w jednym budynku funkcje handlowe, usługowe, wypoczynkowo-rekreacyjne i biznesowe. Z czasem jednak zaczęły one przybierać formę tzw. lifestyle centers ${ }^{13}$. Były to nowe elementy w tkance miejskiej, obejmujace znaczne powierzchnie przeznaczone na handel i usługi, dość luźno wzorowane na uliczkach małych miast. Od tradycyjnych centrów handlowych czy okazjonalnych targowisk i rynków różniły się sposobem zaprojektowania. W ich strukturze znajdowały się zarówno ulice służące komunikacji, jak i zamknięte deptaki, otwarte witryny sklepowe i ekspozycje „wylewajace się” na ulice, a także kompozycje pięcio-, sześciokondygnacyjnych budynków ze zróżnicowaną strukturą użytkowania - mieszkaniową i komercyjną (handlowa, usługowa). Architektura tych przestrzeni nawiązywała zarówno do tradycji (City Place w West Palm Beach, Santana Row w San Jose), jak i nowoczesności (East Twenty-Ninth Avenue Town Center w Denver czy centrum miasta Reston w Wirginii). Jakkolwiek, jak podkreśla Witold Rybczyński, rozwiązania funkcjonujace w Stanach Zjednoczonych nie moga ani nie powinny być w sposób bezpośredni przenoszone na grunt europejski.

Wynika to przede wszystkim z różnic w podejściu do planowania, funkcjonowania i korzystania z centrów miast w Europie i Stanach Zjednoczonych, szczególnie w kontekście sytuowania w miastach centrów handlowych. Struktura historycznego, często koncentrycznego, układu centrów miast europejskich jest diametralnie inna od dominującego w Stanach Zjednoczonych ukła-

12 Nawrocki: Wobronie miasta. Rozmowa Dominika Eaciaka, „Krytyka Polityczna”, http://www. krytykapolityczna.pl/artykuly/miasto/20130526/nawrocki-w-obronie-miasta [dostęp: 1.06.2015].

13 W. Rybczyński, Space: the desing of the urban environment, w: R. P. Inman (ed.), Making Cities Work: Prospects and Policies for Urban America, Princeton University Press, Princeton and Oxford 2009, s. 106-107. 
du prostokątnej siatki ulic. Wpłynęło to na ukształtowanie różnych wzorców korzystania z centrów, szczególnie przez użytkowników pieszych. Europejski przechodzień pokonuje zazwyczaj dłuższe dystanse, w bardziej atrakcyjnej i urozmaiconej przestrzeni. Z ruchu kołowego często są wyłączane całe dzielnice centralne. W Stanach Zjednoczonych przeznaczone tylko dla ruchu pieszego są co najwyżej fragmenty pojedynczych ulic, co i tak często jest przyczyną ich upadku. Użytkownicy samochodów nie są bowiem zainteresowani przestrzeniami, do których nie można bezpośrednio dojechać ${ }^{14}$.

Jakie zatem czynniki mogą mieć kluczowe znaczenie przy przywracaniu centrów miastom i ich mieszkańcom? Tutaj ponownie badania i realizacje amerykańskie sa dalece odmienne od europejskich. Problem wyludniania i spadku zainteresowania obszarami centralnymi w miastach Ameryki Północnej i Środkowej stanowił obszar refleksji badaczy i interwencji władz miejskich już od lat pięćdziesiątych XX w. Pierwotnie próbowano wykorzystać pośrednie oddziaływanie czynników socjoekonomicznych. Przykładem jest chociażby Mexico City, gdzie mieszkańców z obszarów biedy i wykluczenia, zarówno centralnych, jak i peryferyjnych, przenoszono do dzielnic z wyższymi, średnimi dochodami i rozwiniętym rynkiem pracy. Dokonywano kontrolowanego mieszania struktury społecznej i socjalnej. Skutkowało to jednak dalszym drenażem osłabionych i niewydolnych społecznie oraz ekonomicznie dzielnic, przede wszystkim centrów. Tym samym okazało się, że przeceniono znaczenie czynników ekonomicznego i administracyjnego ${ }^{15}$.

Odpowiedzia na nieudane działania miały być manifesty działaczy i aktywistów, m.in. słynne The Death and Life of Great American Cities Jane Jacobs, oraz coraz bardziej krystalizujace się nurty i koncepcje w podejściu do funkcjonowania i przebudowy miast. Na tym gruncie zrodziły się w Stanach Zjednoczonych koncepcje miasta zwartego (compact city), rozwoju prowadzonego w oparciu o tradycyjne sasiedztwo (traditional neigbourhood development), nowego urbanizmu (new urbanism), wzrostu inteligentnego (smart growth), czy w dalszej konsekwencji zrównoważonego urbanizmu (sustainable/ green urbanism). Jako działania mające na celu ożywianie centrów, większość z nich podnosi kwestie: różnicowania funkcjonalnego struktury zabudowy, różnicowania standardu, wielkości, typu oraz sposobu zasiedlania mieszkań, a w efekcie różnicowania tkanki społecznej, wykorzystania komunikacji publicznej, indywidualnej i rowerowej (a w skrajnych wypadkach tylko pieszej) jako podstawowej, szerokiego uspołeczniania procesów planistycznych, inwestycyjnych i rewitalizacyjnych ${ }^{16}$.

Współcześnie działania te są osadzone także w szerokim kontekście środowiskowym, preferuje się określone rozwiąania technologiczne i organizacyjne. W efekcie w centrach dużych miast amerykańskich realizowany jest scenariusz, który opisuje szerzej Elżbieta Litwińska. W prowadzonych tam działaniach rewitalizacyjnych w pierwszej kolejności organizowane są prze-

14 Ibidem, s. 99.

${ }_{15}$ M. Pelling, The Vulnerability of Cities: Natural Disasters and Social Resilience, Earthscan Publications Ltd., London 2003, s. 50.

${ }_{16}$ T. Bradecki, A. Twardoch, Współczesne kierunki kształtowania zabudowy mieszkaniowej, Monografie Politechniki Ślaskiej 510, Wydawnictwo Politechniki Ślasskiej, Gliwice 2013. 
strzenie publiczne i wprowadzane do nich funkcje kulturalno-rozrywkowe (także w formie opisanych lifestyle centers), następnie pojawia się potrzeba mieszkań na wynajem, w dalszej kolejności - mieszkań własnościowych, wreszcie powierzchni biurowych ${ }^{17}$. Skutkuje to zróżnicowaną strukturą funkcjonalna. Wprowadzane są także rozwiązania niestandardowe, jak chociażby słynna rewitalizacja opuszczonych torów kolejowych High Line w Nowym Jorku - przekształcono je w park miejski.

Europejską odpowiedzią na koncepcje ze Stanów Zjednoczonych była przede wszystkim Nowa Karta Ateńska oraz takie koncepcje, jak urban village czy urban renaissance. Większy nacisk kładzie się w nich na takie elementy, jak: ciągłość historyczna, związki międzypokoleniowe, tożsamość społeczna, a także dostępność przestrzenna czy trwałość środowiskowa. Silnie podkreśla się także rolę posiadanego dziedzictwa i dąży do jego zachowania oraz ukierunkowania na skalę „ludzką” (czyli dostosowaną do możliwości percepcji człowieka zarówno jeśli chodzi o odległość, jak i wysokość).

Sztandarowym przykładem podjętych działań praktycznych jest Kopenhaga. Władze tego miasta już w latach sześćdziesiątych XX w. rozpoczęły działania na rzecz redukcji liczby samochodów poruszajacych się po jej centrum, uznając to za kluczowy czynnik przemiany miasta. W 1962 r. zamknęły dla ruchu kołowego główną ulicę i od tego czasu nieustannie podejmują dalsze działania na rzecz ożywienia początkowo tylko centrum, a teraz także kolejnych dzielnic i osiedli ${ }^{18}$. Pod kierunkiem Gehla rozpoczęto długofalowy proces „odzyskiwania miasta”. Systematyczne badania zachowań ludzi w przestrzeni miasta oraz preferowanych sposobów korzystania z przestrzeni stały się podstawą budowania polityki przestrzennej przez władze miejskie.

Nieco odmienne działania podejmowano w dobie transformacji w miastach byłej NRD. Jak podkreśla Andreas Billert, na tym obszarze „najistotniejszymi ogniskami działań i przemian transformacyjnych były miasta i programy ich jakościowego rozwoju"19. Obszary centralne miast byłej NRD borykały się z podobnymi problemami, jak miasta innych krajów europejskich - wysokim wskaźnikiem pustostanów, zbyt dużym zagęszczeniem zabudowy (często pozostającej w złej kondycji), znacznym rozproszeniem własności oraz kumulacja problemów społecznych. Podejmowano więc szeroko zakrojone działania reprywatyzacyjne, modernizacyjne, dokonywano reform szkolnictwa i realizowano rozbudowany program budowy społeczeństwa obywatelskiego. Wszelkie działania były umocowane specjalnymi regulacjami prawnymi (ustawa o wspieraniu rewitalizacji miast) oraz dofinansowywane ze specjalnej puli środków publicznych $^{20}$. Udało się wówczas względnie skutecznie zahamować tendencje suburbanizacyjne i sterować lokalizacjami centrów wielkopowierzchniowych

17 E. Litwińska, Strategia ożywiania centrów dużych miast amerykańskich, „Studia Miejskie” nr 7, Wyd. UO, Opole 2012, s. 71-80.

18 J. Gehl, Cities for People, Island Press, Washington 2010, s. 13.

19 A. Billert, Miasta $w$ postindustrialnej Europie $i w$ kleszczach polskiej transformacji, w: P. Filar, P. Kubicki (red.), Miasto w działaniu, zrównoważony rozwój z perspektywy oddolnej, Instytut Obywatelski, Warszawa 2012, s. 89.

20 A. Billert, Problemy rewitalizacji $w$ Polsce na tle doświadczeń niemieckich, Referat wygłoszony na Międzynarodowej Konferencji w Lubaniu Ślaskim - Rewitalizacji Miast 2006, http:// 
zgodnie z założeniami modelu Miasta Europejskiego, choć efekt ten nie został osiagnięty od razu' ${ }^{21}$. Obecnie w Niemczech działania mające na celu odnowę obszarów centralnych prowadzone są w oparciu m.in. o „Inicjatywę dla śródmieść" (Initiative pro Innenstadt) pod patronatem Ministerstwa Transportu, Budownictwa i Rozwoju Miast, której działalność opiera się na dziesięciu postulatach odnoszących się do znaczenia miast w strukturze terytorialnej kraju, efektywności i zróżnicowaniu wykorzystania terenów miejskich, roli funkcji handlowej, mieszkaniowej, transportowej, bezpieczeństwa oraz oferty kulturalnej ${ }^{22}$.

W nieco bardziej zoperacjonalizowany sposób swoje działania zaplanowały władze Norwegii, gdzie zlecono przeprowadzenie badań odnoszących się do funkcjonalności centrów miast. Objęto nimi centra czterech miast: Oslo, Hamar, Asker, Mosjoen. Znamienne wydaje się w ich wypadku samo sformułowanie celu badania: „wskazanie możliwości wzmocnienia centrów miast jako przestrzeni atrakcyjnych dla handlu i usług”. W badaniach tych podkreślano, że aktualnie stan fizyczny przestrzeni centralnych miast (kondycja budynków, przestrzeni publicznej itp.) jest dobry. W połączeniu z wciąż udoskonalana kwestia dostępności z innych części miasta (transport publiczny, transport indywidualny, miejsca parkingowe, alternatywne formy transportu, jak np. stacje rowerów miejskich) oraz przyjaznością przestrzeni dla ruchu pieszego, związaną z obecnością deptaków, ulic z ograniczonym ruchem kołowym, placów i rynków, centra stanowią atrakcyjne miejsca dla potencjalnych użytkowników. Pojawiają się jednak kluczowe problemy, które utrudniają wykorzystanie w pełni tego potencjału. Zaliczono do nich: 1) rozdrobnienie struktury własnościowej, 2) konkurencję obiektów handlowych zlokalizowanych poza obszarami centralnymi, 3) nasiloną urbanizację poza terenami centrów, która powoduje, że wizyty w centrum nie są koniecznościa, 4) trudności we współpracy wszystkich aktorów, którzy mają bądź mogą mieć związek z ożywieniem centrów ${ }^{23}$. Na podstawie wyników tych badań formułowane są strategie odnowy centrów miejskich i wzmacniania ich jako ośrodków handlowo-usługowych.

Zaprezentowane wyżej przykłady prezentują cztery odmienne podejścia do kwestii ożywiania centrów miast. W koncepcji amerykańskiej dominuje działalność inwestycyjna skoncentrowana na kreacji przestrzeni-miejsca. Ma ono, wraz z konkretną oferta jaką z sobą niesie, przyciagać użytkowników, narzucając im wzorce korzystania z przestrzeni.

W koncepcjach europejskich większą wagę przykłada się do włączenia czynnika społecznego i zachowania potencjału architektoniczno-urbanistycz-

www.poznan.pl $/ \mathrm{mim} / \mathrm{s} 8 \mathrm{a} / \mathrm{attachments} \cdot \mathrm{html}$ ? $\mathrm{co}=$ show \&instance $=1017 \&$ parent $=10805 \& \mathrm{id}=24107$ [dostęp: 12.04.2015].

${ }^{21}$ Por. A. Billert, Miasta..., s. 68 i n., oraz P. Oswalt, U. Steglich, Subsidy culture; a conversation with Ulrich Pfeiffer, w: P. Oswalt (ed.), Shrinking Cities, vol. 1: International Research, Ostfildern: Hatje Cantz Verlag 2005, s. 670-677.

${ }^{22}$ M. Bryx, A. Jadach-Sepioło (red.), Rewitalizacja miast $w$ Niemczech, Instytut Rozwoju Miast, Kraków 2009, s. 119.

${ }^{23}$ A. Tennoy et al., What Can Be Done to Make City Centres More Attractive Locations for Retail and Service?, Institute of Transport Economics, Norwegian Centre for Transport Research, Oslo 2014. 
nego centrów. W działaniach duńskich, które obecnie adaptuje się w wielu innych miastach na świecie (m.in. Londynie, Nowym Jorku, Melbourne, Oakland, Seattle), podstawą była dogłębna analiza zjawisk i procesów zachodzących w przestrzeni między jej użytkownikami. Systematyczna obserwacja zachowań ludzi, „sposobu, w jaki się przechadzaja, jeżdżą na rowerach, spędzają czas przy kawiarnianych stolikach”, analiza wyników i elastyczne dostosowywanie procesów zmian do potrzeb i oczekiwań korzystajacych z centrum dały początek przestrzeniom przez wielu uważanym za wzorcowe ${ }^{24}$. Doświadczenia niemieckie z kolei przenoszą środek ciężkości na opracowanie mechanizmów prawnych i finansowych oraz ich kluczowe znaczenie w procesach zmian. Dopiero regulacje na szczeblu krajowym, poparte państwowym finansowaniem oraz programy realizowane na szczeblu ministerialnym okazały się skutecznym narzędziem ożywiania centrów. Podejście norweskie cechuje się natomiast celowością. Podjęte działania, również zapoczątkowane przez władze krajowe, polegały na celowej analizie przestrzeni centralnych miast i wskazaniu kierunków interwencji w zakładanym obszarze.

\section{DOŚWIADCZENIA POLSKIE}

Kondycja i współczesne przemiany przestrzeni centrów miast polskich, których ścieżka rozwoju była specyficzna, prezentują się nieco inaczej. Począwszy od czasów rodzącego się kapitalizmu, poprzez zniszczenia wojenne, na realnym socjalizmie i okresie transformacji kończąc, a także w efekcie braków koncepcji i strategii zagospodarowania przestrzeni centrów, krótkofalowych planów i projektów urbanistycznych użytkownicy mają do czynienia z przestrzeniami centrów, które nie są dostosowane do ich aktualnych potrzeb. Czy w realiach polskich może zaistnieć przestrzeń, która na te potrzeby mogłaby odpowiadać oraz starać się je zaspokoić? I czy jest to historyczna przestrzeń centrum?

Zarówno opinie badaczy, jak i użytkowników przestrzeni centralnych miast są zróżnicowane. Z jednej strony wieszczy się kryzys centrów zawłaszczonych przez instytucje bankowe i finansowe, wymierajacych po godzinie 18. Jak twierdzą Przemysław Filar i Paweł Kubicki: „Ulice bankowe, które całkowicie zdominowały już śródmieścia naszych miast, stanowią dokładną antytezę miejskości - miasto bez ludzi i drobnych usług w sensie społeczno-kulturowym po prostu nie istnieje" 25 . Z drugiej natomiast - wydaje się, że wszelkie fundamentalne zmiany blokuje zbyt duża waga przywiązywana do czynnika historycznego. Bożena Gierat-Bieroń pyta, czy nie jest tak, że „miasta - opierając swój wizerunek kulturowy o pamięć i dziedzictwo historyczne - przekreślaja

${ }^{24}$ Miasta dla ludzi - rozmowa z Janem Gehlem, „Architektura-Murator” 2009, nr 2, http:// arcastangel.pl/miasta-dla-ludzi-rozmowa-z-janem-gehlem/ [dostęp: 19.04.2015].

${ }_{25}$ P. Filar, P. Kubicki, Lepsze, zrównoważone miasto. Podsumowanie, w: P. Filar, P. Kubicki (red.), op. cit., s. 206. 
w ten sposób szanse na budowanie propozycji będącej ekspresją potrzeb i starań współczesnych mieszkańców?"26.

Jednocześnie wydaje się, że mieszkańcy nie zawsze są zainteresowani zmiana, gdyż nie widzą w tym swojej bezpośredniej korzyści. Skoro bowiem dotychczas nie spędzali czasu w śródmieściu, dlaczego mieliby zmieniać swoje nawyki? Filar podnosi przy tym, że polskie centra niejednokrotnie nie sa nawet na takie zmiany przygotowane. Atrakcyjność oferty handlowej i usługowej śródmieścia nie jest obecnie wystarczająca, aby przyciagnać zmotoryzowanych mieszkańców, równoważąc ich odpływ do lepiej skomunikowanych drogowo centrów handlowych ${ }^{27}$. Pojawiają się także nienowe praktyki, mające swoje źródła w realizacjach postmodernistycznych, w ramach których pojedyncze, efektowne budowle stanowia substytuty kreowania szerszej przestrzeni miejskiej ${ }^{28}$. Wojciech Kosiński upatruje w nich jeden z kluczowych czynników współczesnego kryzysu w kształtowaniu miast, z którym borykają się niejednokrotnie historyczne centra. Przykładami tego typu realizacji sa chociażby budynek Złota 44 w Warszawie czy gdyńskie Sea Towers, ale także niezrealizowane Korona Tower w Poznaniu, Lilium Tower w Warszawie czy koncepcje Polskiego Haka w Gdańsku lub Tuby Silvestrina w Poznaniu.

Polskie doświadczenia z zakresu ożywania przestrzeni centralnych można uznać za skrajnie różne. Z jednej strony są to rozbudowane programy, głównie rewitalizacji, o charakterze masterplanów. Koncentrują w sobie zarówno działania planistyczne, jak i inwestycyjne, społeczne i gospodarcze. Co więcej, nie dzieje się tak tylko z nazwy, a zapisane działania nie sa fasadowe; stanowia rzeczywiście przemyślany scenariusz, poparty szeroka analiza. Do tego typu przykładów należą m.in. doświadczenia Poznania, Szczecina, Sopotu, Lublina, Dzierżoniowa czy Płocka. Równolegle występują jednak przykłady działań o charakterze inwestycyjnym, bez szerszych konsultacji, które nie znajduja poparcia lokalnej społeczności i niekoniecznie przyczyniają się do ożywiania centrów. Należą do nich m.in. dyskusyjne rewitalizacje rynków we Włocławku, Łasku, Skierniewicach, Wadowicach czy Bielsku-Białej. Ich społeczny odbiór jest w przeważającej większości negatywny, prowokują one publiczna dyskusję na temat roli i funkcji terenów centralnych w miastach ${ }^{29}$.

Równie niejednoznaczne sa kwestie lokalizowania w śródmieściach centrów handlowych. Z jednej strony podnosi się kwestię ich ożywczego wpływu na przestrzenie, w których powstały. Sztandarowymi niemal przykładami sa tu poznański Stary Browar lub łódzka Manufaktura. Z drugiej natomiast nieustannie zwraca się uwagę na dokonywany przez nie drenaż ludzi z przestrze-

${ }^{26}$ B. Gierat-Bieroń, Zrównoważony rozwój miasta a kultura, w: P. Filar, P. Kubicki (red.), op. cit., s. 144.

${ }^{27}$ P. Filar, Zrównoważony transport, w: idem, P. Kubicki (red.), op. cit., s. 124.

${ }^{28}$ W. Kosiński, Dobro i piękno - miejsca przyjazne człowiekowi w miastach modernizmu po 1945: idee, projekty, realizacje, „Przestrzeń i Forma” 20, 2013, s. 35-94.

${ }^{29}$ Por. m.in. T. Żółciak, Rewitalizacja po polsku? Zalać plac betonem i zapłacić krocie, „dziennik.pl”, http://wiadomosci.dziennik.pl/wydarzenia/artykuly/465920,rewitalizacja-po-polsku-zalacplac-betonem-wloclawek.html [dostęp: 8.05.2015], czy J. Noch, W internecie burza o „betonowy” rynek we Wtoctawku za 6 mln zt. Tyle wiemy z mema, kogoś obchodzi prawda?, ,natemat”, http:// natemat.pl/111527,w-internecie-burza-o-betonowy-rynek-we-wloclawku-za-6-mln-zl-tyle-wiemy-z-mema-kogos-obchodzi-prawda [dostęp: 8.05.2015]. 
ni publicznych, rynków, placów i deptaków. Cytując Nawrockiego: „Czym innym jest postawienie centrum na peryferiach w Jankach, a czym innym w samym środku miasta. Kosztem życia społecznego" ${ }^{30}$. Doświadczenia poznańskie wskazuja jednak, że nie każdy obiekt handlowo-usługowy w centralnej części miasta jest „skazany na sukces”. Przykładami mogą być Kupiec Poznański czy Galeria MM. Z jednej strony obiekty te nie są tak licznie odwiedzane przez nabywców jak wspomniany Stary Browar, z drugiej - struktura najemców lokali jest w nich odmienna. Dominują sklepy o mniejszych powierzchniach, mniej rozpoznawalnych markach lub też swoiste hybrydy sklepów dyskontowych i sklepów z artykułami codziennego użytku (jak wyjątkowo „kameralny” Lidl zlokalizowany w Galerii MM). Same galerie natomiast nie wpływają istotnie na sposób użytkowania otoczenia - przykładowo wciąz funkcjonują w ich sąsiedztwie placówki handlowe, które działały przed ich powstaniem.

Wydaje się zatem, że coraz częściej dla potencjalnego odbiorcy czynnikiem decydujacym o wyborze takiego, a nie innego miejsca zaspokajania potrzeb nie jest czynnik przestrzenny, ale raczej konkretny element oferty, którego poszukuje i którym jest zainteresowany. Oczywiście może mieć na niego wpływ dostępność, rozumiana jako możliwość dotarcia samochodem i wygodnego oraz bezpłatnego zaparkowania, ale nie jest ona czynnikiem decydujacym. Być może więc istotnym zagrożeniem jest konkurencja różnych podmiotów wychodzacych z podobną oferta, a zlokalizowanych poza przestrzenia publiczną śródmieść - w tym przede wszystkim wielkopowierzchniowych centrów handlowych, które zastępują w coraz szerszym zakresie możliwości realizacji potrzeb przez tradycyjne przestrzenie w miastach, w tym historyczne centra ${ }^{31}$.

\section{PODSUMOWANIE}

Co zatem dalej z przestrzeniami centralnymi miast? Czy sa one jeszcze do czegokolwiek ich mieszkańcom potrzebne? Przynajmniej na etapie deklaratywnym na pewno tak, czego dowodzą choćby badania Tomasza Nawrockiego i Krzysztofa Bierwaczonka ${ }^{32}$. Praktyka pokazuje jednak, że coraz częściej zainteresowanie użytkowników centralnymi placami, rynkami bądź ulicami

${ }^{30}$ Nawrocki: Wobronie miasta. Rozmowa Dominika Eaciaka, „Krytyka Polityczna”, http://www. krytykapolityczna.pl/artykuly/miasto/20130526/nawrocki-w-obronie-miasta [dostęp: 1.06.2015]

${ }^{31}$ A. Rochmińska, Centra handlowe jako przestrzenie hybrydowe, w: E. Klima (red.), Ludność. Mieszkalnictwo. Ustugi - w 70. Rocznice urodzin profesora Jerzego Dzieciuchowicza. Population. Housing. Services - 70 th Anniversary of Professor Jerzy Dzieciuchowicz, „Space-Society-Economy” 13, Department of Population and Services Studies, Wyd. UŁ, Łódź 2014, s. 281-297.

32 W efekcie prowadzonych badań dotyczących przestrzeni centralnych wybranych miast Śląska autorzy sformułowali trzy kluczowe wnioski: 1) nieustająco ważna jest rola archetypu przestrzennego, jakim jest miasto z centralnym punktem - rynkiem, pojawiająca się w waloryzacji przestrzeni miejskiej, 2) badani mieszkańcy doceniają potrzebę funkcjonowania w przestrzeni centralnej miasta oraz 3) częste jest odwoływanie się przez badanych mieszkańców do tradycyjnych wyobrażeń przestrzeni centralnej w kontekście postulowanych zmian jej aktualnego kształtu, por. T. Nawrocki, Od rynku do malla. Zmiany centrów miast ślaskich i ich społeczna percepcja, „Studia Etnologiczne i Antropologiczne” 2010, nr 10, s. 164-176. 
jest znikome. Te w mniejszych miastach pozbawione sa oferty kulturalnej czy rozrywkowej.

W realiach polskich aktualna wydaje się diagnoza i idąca w ślad za nią koncepcja Gehla. Centra miast nie sa przestrzenią atrakcji, nie przyciagają użytkowników, nie zmuszają ich do zatrzymania. Nie sa też dostępne i przyjazne dla pieszych i rowerzystów. Nawet wyłączenie z ruchu poszczególnych ulic, wprowadzenie stref ograniczenia prędkości lub innych rozwiązań uspokajających ruch samochodowy to wciąż niewystarczające działania. Dopiero przykłady kopenhaskie czy nowojorskie dowodza, że ludzi do centrum przyciagaja łatwy dojazd, możliwość przemieszczania się pieszo bądź rowerem, funkcjonowanie otwartych miejsc spotkań, kawiarni, restauracji, klubów z ogródkami otwartymi na ulice, dostępność ławek, obiektów małej architektury i niekończacy się festiwal atrakcji - miejskich plaż, boisk, placów zabaw, przedstawień, koncertów, warsztatów, targów, jarmarków i kiermaszów.

dr Anna Bernaciak

Uniwersytet Ekonomiczny w Poznaniu

anna.bernaciak@ue.poznan.pl

\section{CURRENT TRANSFORMATIONS OF CITY CENTRES IN LIGHT \\ OF SOME AMERICAN AND EUROPEAN EXPERIENCES}

Sum mary

The article is an attempt to answer the questions about the condition of modern central areas and factors that may be critical in returning city centres to cities and their inhabitants. It also addresses the issue of designing thematic centre spaces, wondering if the space organised in this way responds to new needs, or whether it rather leads to their creation.

The main objective of this paper is to present the most important objectives of modern concepts of revitalising the central area of the city and some practical implementation. It points to the accuracy of the results of the European and American experience and the differences in these two approaches. Against this background selected Polish projects are presented. 
